\title{
Measurement of Financial Motivator's Effectiveness in Pharmaceutical Companies in Bangladesh
}

\author{
Dr. Md. Mahbub Sharfaraj \\ Associate Professor, Department Of Management, Government Kabi Nazrul University College, Dhaka, \\ Bangladesh
}

\begin{abstract}
Here the researcher has presented a comparative measurement of financial elements that motivates employees. Like other organizations it is important for the related parties to know what motivates the employees to work. The study on motivation has to determine two major things. First, the degree of need satisfaction of each category as desired by the employees and second, the extent of which such needs are currently being met effectively. These two figures may help in finding out the deficiency, if any in the area of need satisfaction. Motivation theory prescribes us that compensation packages must be designed with employees needs in mind, if the rewards are to create satisfaction and stimulate them to high levels of job productivity. Otherwise, high levels of productivity in job and job satisfaction will not be sustained. Here the researcher has attempted to determine the level of motivation of the employees to the various financial motivators existing in their organization. Thus he has tried to know, whether the employees of the selected companies are motivated or not. To measure the motivation level, Likert's five-point scale has been used. The total number and percentage of respondents belonging to each level of satisfaction have been shown separately.
\end{abstract}

Keywords Correlation, Domestic company, Motivation, Multinational Company, Pharmaceutical.

\section{Introduction}

The importance of Pharmaceutical sector in our economy is well recognized. From the year 2016 the sector is to face international open competition. In the present time pharmaceutical sector of Bangladesh has attained such strength that it can compete in the global free market. To strengthen the pharmaceutical sector, every aspect of this industry is to be examined. For the survival in the global competition there is no alternative to produce better quality products at a minimum cost. Employees are the key to run an industry smoothly and efficiently.

"Employee performance is greatly influenced by their expectancy of what the job will provide, their attitudes toward personal achievement and advancement and their wish for harmony in the workplace" [1] The amount of opportunity people see in their jobs has a direct relationship to their job performance. [2] More and more people joining the workforce today are looking for jobs that not only make money but also have some meaning. Employees want an opportunity for purposeful action and self-advancement. [3] To satisfy the desire to do worthwhile work, a good manager gives thought to placing employees on jobs for which they have the most aptitude, training, and experience.[4] People are willing to put forth the kind of effort that will increase productivity if their needs, goals, expectations, and desires are met. Many factors influence human motivation. "People are motivated through expectations for rewards they value. Worker motivation is also influenced by the nature of the job itself, employment expectations, and physical as well as the emotional make-up of employees."'[5]

We know that all human behavior is motivated. To get the best service of the employees, there is no other way to motivate them. It would be very useful to know that what kind of financial motivational program may stimulate them to work sincerely. In Bangladesh a number of studies on employee motivation have been done. But to the best of the research's knowledge no direct study has so far been undertaken on the pharmaceutical industries.

The findings of this study are expected to be of great use to the domestic and foreign investors, policy makers, students, human right workers, wage commission, International Labor Organization (ILO) and future researchers. This may help in formulating labor policy, industrial policy in future. It is also expected to add new ideas and knowledge to the existing field regarding employee motivation and employee management.

\section{Objectives Of The Study}

The main objectives of the present study are as follows-

1. To identify the existing employee motivational programs (financial) in domestic and multinational Pharmaceutical companies in Bangladesh.

2. To measure the level of motivation of the employees to every financial motivational factor of the selected companies. 
3. To present a comparative study of employee motivational programs between domestic and multinational pharmaceutical companies in Bangladesh.

\section{Selecting Of The Study Area}

Selection of the pharmaceutical companies as the study area has been done on the basis of convenience in collecting data. Pharmaceutical is a very well organized sector in Bangladesh. Most of the Pharmaceutical companies head offices located in Dhaka and the production units near Dhaka. Pharmaceutical companies have their own websites, which are very reliable sources of in modern world. Employees of this sector are main respondents of the study. Respondents are educated, which is very important for a survey. There are 229 registered Pharmaceutical manufacturing units in Bangladesh. [6] Seven companies (five domestic and two multinational) have been chosen for the study. The study has done by surveying 140 employees. 100 employees from five domestic Pharmaceutical companies (20 form each company) and 40 from two multinational companies (20 form each company) are brought under this survey. Seven top executives and fifteen supervisors from seven selected companies are also brought under investigation.

\section{Metodology}

Methodology is the procedural framework within which the research is done. [7] It is the systematic and analytical study of the principles that guides scientific investigation. It describes an approach to a problem that can be put into practice in a research process. Methodology can be defined as, "An operational framework within which the facts are placed, so that their meaning may be seen more clearly."[8] Methodology is foundation of any research. The researcher has to specify some methods for collecting data, processing and analyzing

\subsection{Techniques of data analysis}

Collected data has been processed and analyzed by applying statistical package for the social science (SPSS). Computer has been used widely for analyzing data. Correlation, mean values, $\mathrm{T}$ tests, Chi-square test, percentages, ratios have been used wherever, which one is appropriate. To measure the motivation level Likert's five point scale has been used. The scales used are: highly satisfied, satisfied, neutral, dissatisfied and highly dissatisfied. The scores allotted are five, four, three, two, one respectively. The total number and percentage of respondents belonging to each level of satisfaction have been shown separately.

\subsubsection{What is a Likert scale?}

A Likert scale measures the extent to which a person agrees or disagrees with the question. The most common scale is 1 to 5 . Often the scale will be $1=$ strongly disagree, $2=$ disagree, $3=$ not sure, $4=$ agree and $5=$ strongly agree.

\subsubsection{What is SPSS?}

The abbreviation SPSS stands for Statistical Package for the Social Sciences. This package of programs is available for both personal and mainframe (or multi user) computers. [9] These programs are being continuously updated and so there are various versions in existence. In this study the researcher has used the SPSS version 7.5 .

\subsubsection{Correlation}

The idea of Correlation is one of the most important and basic in the elaboration of bipartite relationship. Unlike chi-square, measures of correlation indicate both the strength and the direction of the relationship between a pair of variables. Two types of measures can be distinguished: measures of linear Correlation using interval variables and measures of rank Correlation using ordinal variables. While these two types of measures of Correlation share some common properties, they also differ in some important aspects which will be examined after the elucidation of measures of linear Correlation. [10]

\subsubsection{Chi-square test}

If we want to compare the observed frequencies of cases with those expected in a variable that has more than two categories, then we use chi-square (pronounced kye square) test rather than a binominal test. If we want to compare the frequency of cases found in one variable in two or more unrelated samples or categories of another variable, we will also use test. [11] 


\section{Definition of the key terms}

The purpose of this study is to analyze motivational programs of pharmaceutical industries in Bangladesh. Some terms have been used here repeatedly, which have specific meanings and significance. So this is important to define and discuss the terms/concepts those have been used in this study.

\subsection{Employee}

Usually employee is one who is employed by another, who works for wages or salaries in the service of an employer. Here employee means permanent staff of a company, working in any department. Her only unionized permanent people have been considered as employees.

\subsection{Motivation}

Motivation is the mental force, which makes an individual willing to carryout his duties and responsibilities for the achievement of the goals of his organization. Motivation is the work manager to inspire, encourage and impel people to take required action. [12] Motivation is the cause of human behavior. It may be stated as the key to unlock the power of a person, which already exists in him.

\subsection{Multinational Company}

Multinational Company means a company that has been operating in Bangladesh but its origin may be in any country other than Bangladesh.

\subsection{Domestic Company}

Domestic Company (DC) means an organization whose origin is in Bangladesh. Such a company is controlled and registered under the Bangladesh company law 1994. Here the term domestic company has been used for Bangladeshi public or private limited company or any other company formed and operated abiding Bangladesh government rules and orders.

\subsection{Productivity}

Productivity is related with production. It is actually the ratio of input and output. It indicates the effectiveness of production process.

\section{Comparative Measurement of Motivation Effectiveness in Domestic and Multinational Pharmaceutical Companies in Bangladesh}

In this paper the researcher has presented a comparative measurement of elements that motivates employees. Like other organizations it is important for the related parties to know what motivates the employees to work. The study on motivation has to determine two major things. First, the degree of need satisfaction of each category as desired by the employees and second, the extent of which such needs are currently being met effectively. These two figures may help in finding out the deficiency, if any in the area of need satisfaction. [13] Motivation theory prescribes us that compensation packages must be designed with employees needs in mind if the rewards are to create satisfaction and stimulate them to high levels of job productivity. Otherwise, high levels of productivity in job and job satisfaction will not be sustained. [14] Here the researcher has attempted to determine the level of motivation of the employees to the various financial motivators existing in their organization. Thus he has tried to know, whether the employees of the selected companies are motivated or not. To measure the motivation level, Likert's five-point scale has been used. The scales used are: highly satisfied, satisfied, neural, dissatisfied, and highly dissatisfied. The scores allotted are five, four, three, two and one respectively. The total number and percentage of respondents belonging to each level of satisfaction have been shown separately.

Here the level of motivation of the employees to each financial factor has shown below-

\subsection{Motivation and Wages and Salaries:}

Wages and salaries is a highly important factor of financial elements of motivation. It enables the employees to meet their basic needs. The following table (table-1) shows that, about 13 percent employees of domestic companies are highly satisfied with their present wages and salaries, when the percentage of highly motivated employees in multinational pharmaceutical companies is 70 . About 57 percent of the employees of domestic companies are satisfied, when the percentage of satisfied employees of multinational companies are 30. About 30 percent of the employees of domestic companies are reluctant to clear their satisfaction or dissatisfaction they are neutral. Total tally of highly satisfied employees are 29.3 percent, satisfied 49.3 percent and neutral 21.4 percent. No employees of domestic pharmaceutical companies or multinational pharmaceutical companies found dissatisfied or highly dissatisfied with wages and salaries. The chi-square value between wages and salaries and company types is 47.924 , which is highly significant i.e. there is an 
association between wages and salaries and types of companies. That is motivation has been changing because of company's types.

\section{TABLE-1}

Percentage distribution of satisfaction level of employees with their wages and salaries. (Figures in parenthesis are in percentages)

$\begin{array}{ll}\text { Type of Company } & \begin{array}{l}\text { Wages and } \\ \text { Highly } \\ \text { dissatisfied }\end{array} \\ \text { Domestic } & 0 \\ \text { Multinational } & (0) \\ \text { Total } & 0 \\ & (0) \\ & 0\end{array}$

(0) ages and salaries

Dissatisfied Neutral

$0 \quad 30$

(0)

0

(0)

0

(0)

$\begin{array}{ll}\text { Neutral } & \text { Satisfied } \\ 30 & 57 \\ (30.0) & (57.0) \\ 0 & 12 \\ (0) & (30.0) \\ 30 & 69 \\ (21.4) & (49.3)\end{array}$

Highly
satisfied
13
$(13.0)$
28
$(70.00$
41

Total

Index

100

(100)

40

(100)

140

(29.3)

$\mathrm{X} 2=47.924(\mathrm{p}<0.000)$

\subsection{Motivation and House Rent}

The following table (table-2) shows that, 55 percent employees of domestic companies are satisfied with their present house rent, when the percentage of satisfied employees of Multinational pharmaceutical companies is 72.5. About 15 percent of the employees of multinational companies are highly satisfied; when nobody of domestic companies is found highly satisfied. One percent of employee of domestic pharmaceutical companies are found dissatisfied. About 44 percent of the employees of domestic companies are reluctant to clear their satisfaction or dissatisfaction they are neutral,when percentage of neutral employees in multinational companies is 12.5. Total tally of highly satisfied employees are 4.3 percent, satisfied 60 percent, neutral 35 percent and dissatisfied .7 percent. No employees of domestic pharmaceutical companies or Multinational pharmaceutical companies is found highly dissatisfied. The Chi-square value between house rent and company types is 24.958 , which is highly significant i.e. there is an association between house rent and types of companies. That is motivation has been changing because of company's types.

TABLE -2

Percentage distribution of satisfaction level of employee with House Rent. (Figures in parenthesis are in percentages)

\begin{tabular}{|c|c|c|c|c|c|c|c|}
\hline \multirow[t]{2}{*}{ Type of Company } & \multicolumn{2}{|c|}{ House Rent } & & & \multicolumn{2}{|r|}{ Total } & Index \\
\hline & $\begin{array}{l}\text { Highly } \\
\text { dissatisfied }\end{array}$ & Dissatisfied & Neutral & Satisfied & $\begin{array}{l}\text { Highly } \\
\text { satisfied }\end{array}$ & & \\
\hline Domestic & $\begin{array}{l}0 \\
\text { (0) }\end{array}$ & $\begin{array}{l}1 \\
(1)\end{array}$ & $\begin{array}{l}44 \\
(44)\end{array}$ & $\begin{array}{l}55 \\
(55)\end{array}$ & $\begin{array}{l}0 \\
(0)\end{array}$ & $\begin{array}{l}100 \\
(100)\end{array}$ & .98 \\
\hline Multinational & $\begin{array}{l}0 \\
(0)\end{array}$ & $\begin{array}{l}0 \\
(0)\end{array}$ & $\begin{array}{l}5 \\
(12.5)\end{array}$ & $\begin{array}{l}29 \\
(72.5)\end{array}$ & $\begin{array}{l}6 \\
(15)\end{array}$ & $\begin{array}{l}40 \\
(100)\end{array}$ & .98 \\
\hline Total & $\begin{array}{l}0 \\
(0)\end{array}$ & $\begin{array}{l}1 \\
(.7)\end{array}$ & $\begin{array}{l}49 \\
(35.0)\end{array}$ & $\begin{array}{l}84 \\
(60.0)\end{array}$ & $\begin{array}{l}6 \\
(4.3)\end{array}$ & $\begin{array}{l}140 \\
(100)\end{array}$ & .99 \\
\hline
\end{tabular}

\subsection{Motivation and Medical Allowance}

The table (table-3) shows that, 16 percent employees of domestic companies are satisfied with their existing medical allowance, when the percentage of satisfied employees in case of Multinational pharmaceutical companies is 45. Six percent of the employees of domestic companies are dissatisfied; when 5 percent employees of multinational companies are dissatisfied. One percent employees of domestic pharmaceutical companies is found highly dissatisfied, but nobody of Multinational pharmaceutical companies is highly dissatisfied. About 77 percent of the employees of domestic companies are reluctant to clear their satisfaction or dissatisfaction they are neutral, when percentage of neutral employees in multinational companies is 50. Total tally of satisfied employees are 24.3 percent, neutral 69.3 percent, dissatisfied 5.7 percent and highly dissatisfied .7 percent. No employee of Domestic pharmaceutical companies or multinational pharmaceutical is found highly satisfied.

The Chi-square value between medical allowance and company types is 13.350 , which is highly significant i.e. there is an association between medical allowance and types of companies. That is motivation has been changing because of company's types. 
TABLE -3

Percentage distribution of satisfaction level of employees with Medical Allowance. (Figures in parenthesis are in percentages)

Type of Company

\begin{tabular}{llll}
\multicolumn{3}{c}{ Medical Allowance } \\
$\begin{array}{l}\text { Highly } \\
\text { dissatisfied }\end{array}$ & Dissatisfied & Neutral & Satisfied \\
1 & 6 & 77 & 16 \\
$(1)$ & $(6)$ & $(77)$ & $(16)$ \\
0 & 2 & 20 & 18 \\
$(0)$ & $(5)$ & $(50.0)$ & $(45.0)$ \\
1 & 8 & 97 & 34 \\
$(.7)$ & $(5.7)$ & $(69.3)$ & $(24.3)$
\end{tabular}

$\begin{array}{lll}\text { Highly } & \text { Total } & \text { Index } \\ \text { satisfied } & & \\ 0 & 100 & .86 \\ (0) & (100) & \\ 0 & 40 & .90 \\ (0) & (100) & \\ 0 & 140 & .87 \\ (0) & (100) & \end{array}$

$\mathrm{x} 2=13.350(\mathrm{p}<0.000)$

\subsection{Motivation and Gratuity}

The table (table-4) shows that, 1 percent employee of domestic companies is highly satisfied with the existing gratuity, when the percentage of highly satisfied employees in case of Multinational pharmaceutical companies are 2.5. Nine percent of the employees of domestic companies are satisfied; when 20 percent employees of multinational companies are satisfied. About 71 percent of the employees of domestic companies are reluctant to clear their satisfaction or dissatisfaction they are neutral, when percentage of neutral employees in multinational companies is 67.5. Nineteen percent employees of Domestic pharmaceutical companies are found highly dissatisfied, when 10 percent of employees of Multinational pharmaceutical companies are dissatisfied. Overall, highly satisfied employees are 1.4 percent, satisfied 12.1 percent, neutral 70 percent and dissatisfied 16.4 percent. No employee of Domestic pharmaceutical companies or Multinational pharmaceutical companies is highly satisfied with their gratuity.

The Chi-square value between gratuity and salaries and company types is 4.756, which is not significant i.e. there is no association between gratuity and types of companies.

TABLE -4

Percentage distribution of satisfaction level of employees with Gratuity. (Figures in parenthesis are in percentages)

$\begin{array}{ll}\text { Type of Company } & \text { Highly } \\ & \text { dissatisfied } \\ \text { Domestic } & 0 \\ \text { Multinational } & (0) \\ \text { Total } & 0 \\ & (0) \\ & 0\end{array}$

$\begin{array}{rll}\begin{aligned} \text { Gratuity } \\ \text { Dissatisfied }\end{aligned} & \text { Neutral } & \text { Satisfied } \\ 19 & 71 & 9 \\ (19) & (71) & (9) \\ 4 & 27 & 8 \\ (10) & (67.5) & (20) \\ 23 & 98 & 17 \\ (16.4) & (70.0) & (12.1)\end{array}$

Highly
satisfied
1
$(1)$
1
$(2.5)$
2
$(1.4)$

Total

Index

$100 \quad .62$

$(100)$

40

(100)

140

$(100)$

$\mathrm{x} 2=4.756(\mathrm{p}<0.191)$

\subsection{Motivation and Group Insurance}

The table (table-5) shows that, 11 percent of the employees of domestic companies are satisfied; when 7.5 percent employees of multinational companies are satisfied with their group insurance. About 41 percent of the employees of domestic companies are reluctant to clear their satisfaction or dissatisfaction they are neutral, when percentage of neutral employees in multinational companies were 75.42 percent employees of Domestic pharmaceutical companies are found dissatisfied, when 17.5 percent of employees of Multinational pharmaceutical companies are dissatisfied. Six percent of the employees of Domestic pharmaceutical companies are highly dissatisfied, but none of Multinational pharmaceutical companies is highly dissatisfied. Overall 10 percent of employees are satisfied, 50.7 percent are neutral, and 35 percent dissatisfied and 4.3 percent are highly dissatisfied. No employee of Domestic pharmaceutical companies or Multinational pharmaceutical companies is highly satisfied with their group insurance.

The Chi-square value between group insurance and company types is 14.163 , which is highly significant i.e. there is an association between group insurance and types of companies. That is motivation has been changing because of companies types. 
TABLE -5

Percentage distribution of satisfaction level of employees with Group Insurance. (Figures in parenthesis are in percentages)

Type of Company

$\begin{array}{llll}\text { Highly } & \begin{array}{c}\text { Group Insurance } \\ \text { Dissatisfied }\end{array} & \text { Neutral } & \text { Satisfied } \\ \text { dissatisfied } & 42 & 41 & 11 \\ 6 & (42) & (41) & (11) \\ (6) & 7 & 30 & 3 \\ 0 & (17.5) & (75) & (7.5) \\ (0) & 49 & 71 & 14 \\ 6 & (35.0) & (50.7) & (10)\end{array}$

$\begin{array}{lll}\begin{array}{l}\text { Highly } \\ \text { satisfied }\end{array} & \text { Total } & \text { Index } \\ 0 & & \\ (0) & 100 & .04 \\ 0 & (100) & \\ (0) & 40 & .65 \\ 0 & (100) & \\ (0) & 140 & .21 \\ & (100) & \end{array}$

$\mathrm{x} 2=14.163(\mathrm{p}<0.000)$

\subsection{Motivation and Share of Profit}

The table (table-6) shows that, 5 percent employees of domestic companies are highly satisfied with their existing share of profit, when the percentages of highly satisfied employees in Multinational pharmaceutical companies are 2.5. Forty percent of the employees of domestic companies are satisfied; when 50 percent employees of multinational companies are satisfied. About 50 percent of the employees of domestic companies are reluctant to clear their satisfaction or dissatisfaction they are neutral, when percentage of neutral employees in multinational companies is 2.5. Five percent employees of Domestic pharmaceutical companies are found highly dissatisfied; in Multinational pharmaceutical companies 2.5 percent employees are dissatisfied. Total tally of highly satisfied employees are 4.3 percent, satisfied 41.4 percent, neutral 50 percent and dissatisfied 4.3 percent. No employee of Domestic pharmaceutical companies or Multinational pharmaceutical companies is found highly dissatisfied.

The Chi-square value between share of profit and company types is 1.006, which is not significant i.e. there is no association between share of profit and types of companies.

\section{TABLE -6}

Percentage distribution of satisfaction level of employees with share of profit (Figures in parenthesis are in percentage)

\begin{tabular}{|c|c|c|c|c|c|c|c|}
\hline \multirow[t]{2}{*}{ Type of Company } & \multicolumn{2}{|c|}{ share of profit } & & & & Total & Index \\
\hline & $\begin{array}{l}\text { Highly } \\
\text { dissatisfied }\end{array}$ & Dissatisfied & Neutral & Satisfied & $\begin{array}{l}\text { Highly } \\
\text { satisfied }\end{array}$ & & \\
\hline Domestic & $\begin{array}{l}0 \\
(0)\end{array}$ & $\begin{array}{l}5 \\
(5)\end{array}$ & $\begin{array}{l}50 \\
(50.0)\end{array}$ & $\begin{array}{l}40 \\
(40.0)\end{array}$ & $\begin{array}{l}5 \\
(5.0)\end{array}$ & $\begin{array}{l}100 \\
(100)\end{array}$ & .90 \\
\hline Multinational & $\begin{array}{l}0 \\
(0)\end{array}$ & $\begin{array}{l}1 \\
(2.5)\end{array}$ & $\begin{array}{l}20 \\
(50.0)\end{array}$ & $\begin{array}{l}18 \\
(45.0)\end{array}$ & $\begin{array}{l}1 \\
(2.5)\end{array}$ & $\begin{array}{l}40 \\
(100)\end{array}$ & .95 \\
\hline Total & $\begin{array}{l}0 \\
(0)\end{array}$ & $\begin{array}{l}6 \\
(4.3)\end{array}$ & $\begin{array}{l}70 \\
(50.0)\end{array}$ & $\begin{array}{l}58 \\
(41.4)\end{array}$ & $\begin{array}{l}6 \\
(4.3)\end{array}$ & $\begin{array}{l}140 \\
(100)\end{array}$ & .91 \\
\hline
\end{tabular}

$\mathrm{x} 2=1.006(\mathrm{p}<.800)$

\subsection{Motivation and Bonus}

The table (table-7) shows that, two percent employees of domestic companies are highly satisfied with their existing bonus, when the percentage of highly satisfied employees in case of Multinational pharmaceutical companies is 20.33 percent of the employees of domestic companies are satisfied; when 52.5 percent employees of multinational companies are satisfied. About 64 percent of the employees of domestic companies are reluctant to clear their satisfaction or dissatisfaction they are neutral, when percentage of neutral employees in multinational companies is 27.5. One percent employee of Domestic pharmaceutical companies is found dissatisfied; no employee of Multinational pharmaceutical companies is dissatisfied. Total tally of highly satisfied employees are 7.1 percent, satisfied 38.6 percent, neutral 53.6 percent and dissatisfied .7 percent. No employee of Domestic pharmaceutical companies or Multinational pharmaceutical companies is found highly dissatisfied.

The Chi-square value between bonus and company types is 23.282 , which is highly significant i.e. there is an association between bonus and types of companies. That is motivation has been changing because of companies type. 
TABLE -7

Percentage distribution of satisfaction level of employees with Bonus. (Figures in parenthesis are in percentages)

\begin{tabular}{|c|c|c|c|c|c|c|c|}
\hline \multirow[t]{2}{*}{ Type of Company } & \multicolumn{3}{|c|}{ Bonus } & & & \multirow[t]{2}{*}{ Total } & \multirow[t]{2}{*}{ Index } \\
\hline & $\begin{array}{l}\text { Highly } \\
\text { dissatisfied }\end{array}$ & Dissatisfied & Neutral & Satisfied & $\begin{array}{l}\text { Highly } \\
\text { satisfied }\end{array}$ & & \\
\hline \multirow[t]{2}{*}{ Domestic } & 0 & 1 & 64 & 33 & 2 & 100 & .98 \\
\hline & (0) & (1) & (64) & (33) & (2) & (100) & \\
\hline \multirow[t]{2}{*}{ Multinational } & 0 & 0 & 11 & 21 & 8 & 40 & 1.00 \\
\hline & $(0)$ & $(0)$ & $(27.5)$ & $(52.5)$ & (20) & $(100)$ & \\
\hline \multirow[t]{2}{*}{ Total } & 0 & 1 & 75 & 54 & 10 & 140 & .99 \\
\hline & (0) & (.7) & (53.6) & (38.6) & (7.1) & (100) & \\
\hline
\end{tabular}

$\mathrm{x} 2=23.282(\mathrm{p}<0.000)$

\subsection{Motivation and Promotion}

The table (table Bonus- 8) shows that, 14 percent employees of domestic companies are satisfied with their existing promotion facilities, when no employee of Multinational pharmaceutical companies is satisfied. About 42 percent of the employees of domestic companies are reluctant to clear their satisfaction or dissatisfaction they are neutral, when percentage of neutral employees in multinational companies is 30.39 percent of the employees of domestic companies are dissatisfied; when 70 percent employees of multinational companies are dissatisfied. Five percent employees of Domestic pharmaceutical companies are found highly dissatisfied, but nobody of Multinational pharmaceutical companies is dissatisfied. Total tally of satisfied employees are 10 percent, neutral 38.6 percent, dissatisfied 47.9 percent and highly dissatisfied 3.5 percent. No employee of Domestic pharmaceutical companies or Multinationals pharmaceutical companies is found highly satisfied.

The Chi-square value between promotion and company types is 14.404 , which is highly significant i.e. there is an association between promotion and types of companies. That is motivation has been changing because of companies type.

\section{TABLE -8}

Percentage distribution of satisfaction level of employees with promotion. (Figures in parenthesis are in percentages)

\begin{tabular}{|c|c|c|c|c|c|c|c|}
\hline \multirow{2}{*}{ Type of Company } & \multicolumn{3}{|c|}{ Motivation and Promotion } & & & \multirow[t]{2}{*}{ Total } & \multirow[t]{2}{*}{ Index } \\
\hline & $\begin{array}{l}\text { Highly } \\
\text { dissatisfied }\end{array}$ & Dissatisfied & Neutral & Satisfied & $\begin{array}{l}\text { Highly } \\
\text { satisfied }\end{array}$ & & \\
\hline \multirow[t]{2}{*}{ Domestic } & 5 & 39 & 42 & 14 & 0 & 100 & .12 \\
\hline & (5) & (39) & (42) & (14) & $(0)$ & $(100)$ & \\
\hline \multirow[t]{2}{*}{ Multinational } & 0 & 28 & 12 & 0 & 0 & 40 & -.40 \\
\hline & $(0)$ & (70) & $(30.0)$ & (0) & (0) & $(100)$ & \\
\hline \multirow[t]{2}{*}{ Total } & 5 & 67 & 54 & 14 & 0 & 140 & -.03 \\
\hline & $(3.5)$ & (47.9) & $(38.6)$ & $(10.0)$ & (0) & $(100)$ & \\
\hline
\end{tabular}

$\mathrm{X} 2=14.404(\mathrm{p}<0.000)$

\subsection{Motivation Transport allowance}

The table (table-9) shows that, 49 percent employees of domestic companies are highly dissatisfied with their existing transport allowance, when the percentage of highly dissatisfied employees of Multinational pharmaceutical companies is 55. Forty six percent of the employees of domestic companies are dissatisfied; when 55 percent of the employees of multinational companies are dissatisfied. About 5 percent of the employees of domestic companies are reluctant to clear their satisfaction or dissatisfaction they are neutral, when percentage of neutral employees in multinational companies is 2.5. Total highly dissatisfied employees are 47.1 percent, dissatisfied 48.6 percent and neutral 4.3 percent. No employee of Domestic pharmaceutical companies or Multinational pharmaceutical companies is found highly satisfied or satisfied.

The Chi-square value between transport allowance and company types is 1.149 , which is not significant i.e. there is no association between transport allowance and types of companies.

\section{TABLE -9}

Percentage distribution of satisfaction level of employees with Transportation Allowance. (Figures in parenthesis are in percentages)

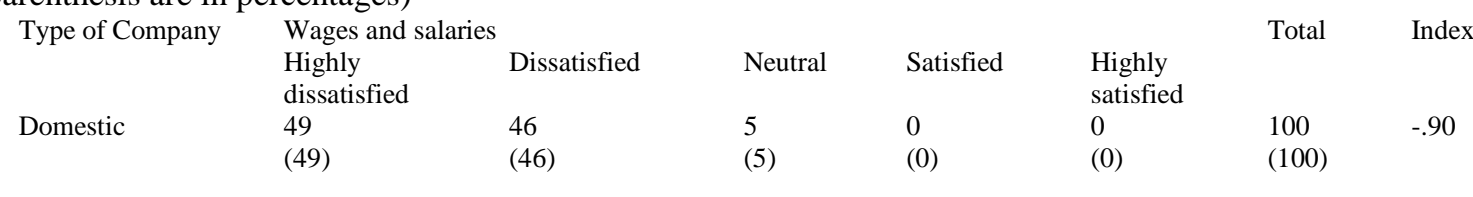




\begin{tabular}{|c|c|c|c|c|c|c|c|}
\hline Multinational & 17 & 22 & 1 & 0 & 0 & 40 & -.95 \\
\hline Total & $\begin{array}{l}(42.5) \\
66\end{array}$ & $\begin{array}{l}\text { (55) } \\
68\end{array}$ & $\begin{array}{l}(2.5) \\
6\end{array}$ & $\begin{array}{l}\text { (0) } \\
0\end{array}$ & $\begin{array}{l}\text { (0) } \\
0\end{array}$ & $\begin{array}{l}(100) \\
140\end{array}$ & -96 \\
\hline
\end{tabular}

\subsection{Motivation and Canteen Subsidy}

The table (table-10) shows that, 14 percent employees of domestic companies are satisfied with their existing canteen subsidy, when the percentage of satisfied employees of Multinational pharmaceutical companies is 2.5 . Twenty percent of the employees of domestic companies are dissatisfied, when also 20 percent employees of multinational companies are dissatisfied, 2.5 percent employees of Multinational pharmaceutical companies are found highly dissatisfied, but nobody of Domestic pharmaceutical companies is dissatisfied. About 66 percent of the employees of domestic companies are reluctant to clear their satisfaction or dissatisfaction they are neutral, when percentage of neutral employees in multinational companies is 75 . Total tally of satisfied employees are 10.7 percent, neutral 68.6 percent, dissatisfied 20 percent and highly dissatisfied 0.7 percent. No employee of domestic or multinational pharmaceutical companies is found highly satisfied.

The chi-square value between canteen subsidy and company types is 6.364 , which is not significant i.e. there is no association between canteen subsidy and types of companies.

Table- 10: Percentage distribution of satisfaction level of employees with canteen subsidy. (Figures in parenthesis are in percentages)

\begin{tabular}{|c|c|c|c|c|c|c|c|}
\hline \multirow[t]{2}{*}{ Type of Company } & \multicolumn{3}{|c|}{ Motivation and Canteen Subsidy } & \multirow[b]{2}{*}{ Satisfied } & \multirow[b]{2}{*}{$\begin{array}{l}\text { Highly } \\
\text { satisfied }\end{array}$} & \multirow[t]{2}{*}{ Total } & \multirow[t]{2}{*}{ Index } \\
\hline & $\begin{array}{l}\text { Highly } \\
\text { dissatisfied }\end{array}$ & Dissatisfied & Neutral & & & & \\
\hline Domestic & $\begin{array}{l}0 \\
(0)\end{array}$ & $\begin{array}{l}20 \\
(20)\end{array}$ & $\begin{array}{l}66 \\
(66)\end{array}$ & $\begin{array}{l}14 \\
(14)\end{array}$ & $\begin{array}{l}0 \\
(0)\end{array}$ & $\begin{array}{l}100 \\
(100)\end{array}$ & .06 \\
\hline Multinational & $\begin{array}{l}1 \\
(2.5)\end{array}$ & $\begin{array}{l}8 \\
(20)\end{array}$ & $\begin{array}{l}30 \\
(75.0)\end{array}$ & $\begin{array}{l}1 \\
(2.5)\end{array}$ & $\begin{array}{l}0 \\
(0)\end{array}$ & $\begin{array}{l}40 \\
(100)\end{array}$ & .55 \\
\hline Total & $\begin{array}{l}1 \\
(.7)\end{array}$ & $\begin{array}{l}28 \\
(20.00)\end{array}$ & $\begin{array}{l}96 \\
(68.6)\end{array}$ & $\begin{array}{l}15 \\
(10.7)\end{array}$ & $\begin{array}{l}0 \\
(0)\end{array}$ & $\begin{array}{l}140 \\
(100)\end{array}$ & .59 \\
\hline
\end{tabular}

\subsection{Motivation and Special Cash Reward}

The table (table-11) shows that, 12 percent employees of domestic companies are satisfied with their existing special cash reward, when the percentage of satisfied employees in case of Multinational pharmaceutical companies is 10 . Twenty percent of the employees of domestic companies are dissatisfied, also 20 percent employees of multinational companies are dissatisfied, One percent of employees of Domestic pharmaceutical companies are found highly dissatisfied, but nobody of Multinational pharmaceutical companies is dissatisfied. About 67 percent of the employees of domestic companies are reluctant to clear their satisfaction or dissatisfaction - they are neutral, when percentage of neutral employees in multinational companies is 70 . Total tally of satisfied employees are 11.4 percent, neutral 67.9 percent, dissatisfied 20 percent and highly dissatisfied 0.7 percent. No employee of domestic or multinational pharmaceutical companies is found highly satisfied.

The chi-square value between Special Cash Reward and company types is .538, which is not significant i.e. there is no association between Special Cash Reward and types of companies.

\section{TABLE - 11}

Percentage distribution of satisfaction level of employees with Special Cash Reward. (Figures in parenthesis are in percentages)

\begin{tabular}{|c|c|c|c|c|c|c|c|}
\hline \multirow{2}{*}{ Type of Company } & \multicolumn{2}{|c|}{ Special Cash Reward } & \multirow[b]{2}{*}{ Neutral } & \multirow[b]{2}{*}{ Satisfied } & \multirow[b]{2}{*}{$\begin{array}{l}\text { Highly } \\
\text { satisfied }\end{array}$} & \multirow[t]{2}{*}{ Total } & \multirow[t]{2}{*}{ Index } \\
\hline & $\begin{array}{l}\text { Highly } \\
\text { dissatisfied }\end{array}$ & Dissatisfied & & & & & \\
\hline \multirow[t]{2}{*}{ Domestic } & 1 & 20 & 67 & 12 & 0 & 100 & .58 \\
\hline & (1) & (20) & $(67.0)$ & (12) & (0) & $(100)$ & \\
\hline \multirow[t]{2}{*}{ Multinational } & 0 & 8 & 28 & 4 & 0 & 40 & 60 \\
\hline & $(0)$ & $(20)$ & $(70.0)$ & $(10)$ & $(0)$ & $(100)$ & \\
\hline \multirow[t]{2}{*}{ Total } & 1 & 28 & & & 0 & 140 & .59 \\
\hline & $(.7)$ & $(20.00)$ & $(69.9)$ & $(11.4)$ & $(0)$ & $(100)$ & \\
\hline
\end{tabular}

\subsection{Motivation and Leave with Pay}

The table (table-12) shows that, 15 percent employees of domestic companies are satisfied with their existing leave with pay, when the percentage of satisfied employees in Multinational pharmaceutical companies is 5. Fifteen percent of the employees of domestic companies are dissatisfied, when 30 percent employees of 
multinational companies are dissatisfied, about 70 percent of employees of Domestic pharmaceutical companies are reluctant to clear their satisfaction or dissatisfaction - they are neutral, when percentage of neutral employees in multinational companies is 65 , Total tally of satisfied employees are 12.1 percent, neutral 68.6 percent and dissatisfied 19.3 percent. No employee of domestic or multinational pharmaceutical companies is found highly satisfied or highly dissatisfied.

The chi-square value between Leave with Pay and company types is 5.790, which is not significant i.e. there is no association between Leave with Pay and types of companies.

\section{TABLE - 12}

Percentage distribution of satisfaction level of employees with Leave with Pay. (Figures in parenthesis are in percentages)

\begin{tabular}{|c|c|c|c|c|c|c|c|}
\hline \multirow[t]{2}{*}{ Type of Company } & \multicolumn{2}{|c|}{ Leave with Pay } & & & & \multirow[t]{2}{*}{ Total } & \multirow[t]{2}{*}{ Index } \\
\hline & $\begin{array}{l}\text { Highly } \\
\text { dissatisfied }\end{array}$ & Dissatisfied & Neutral & Satisfied & $\begin{array}{l}\text { Highly } \\
\text { satisfied }\end{array}$ & & \\
\hline Domestic & $\begin{array}{l}0 \\
(0)\end{array}$ & $\begin{array}{l}15 \\
(15)\end{array}$ & $\begin{array}{l}70 \\
(70)\end{array}$ & $\begin{array}{l}15 \\
(15)\end{array}$ & $\begin{array}{l}0 \\
(0)\end{array}$ & $\begin{array}{l}100 \\
(100)\end{array}$ & .70 \\
\hline Multinational & $\begin{array}{l}0 \\
(0)\end{array}$ & $\begin{array}{l}12 \\
(30)\end{array}$ & $\begin{array}{l}26 \\
(65.0)\end{array}$ & $\begin{array}{l}2 \\
(5)\end{array}$ & $\begin{array}{l}0 \\
(0)\end{array}$ & $\begin{array}{l}40 \\
(100)\end{array}$ & .40 \\
\hline Total & $\begin{array}{l}1 \\
(.7)\end{array}$ & $\begin{array}{l}27 \\
(19.3)\end{array}$ & $\begin{array}{l}96 \\
(68.6)\end{array}$ & $\begin{array}{l}17 \\
(12.1)\end{array}$ & $\begin{array}{l}0 \\
(0)\end{array}$ & $\begin{array}{l}140 \\
(100)\end{array}$ & .61 \\
\hline
\end{tabular}

\subsection{Motivation and Loan Facilities}

The table (table-13) shows that, 4 percent employees of domestic companies are satisfied with their existing loan facilities, when no employees in Multinational pharmaceutical companies found satisfied. Forty three percent of the employees of domestic companies are dissatisfied, when 65 percent employees of multinational companies are dissatisfied, Nineteen percent of employees of Domestic pharmaceutical companies are found highly dissatisfied and 15 percent employees of the multinational companies highly dissatisfied. About 34 percent of employees of Domestic pharmaceutical companies are reluctant to clear their satisfaction or dissatisfaction - they are neutral, when percentage of neutral employees in multinational companies is 20 , Total tally of satisfied employees are 2.9 percent, neutral 30.00 percent and dissatisfied 49.3 percent and highly dissatisfied 17.9 percent. No employee of domestic or multinational pharmaceutical companies is found highly satisfied.

The chi-square value between loan facilities and company types is 6.528 , which is not significant i.e. there is no association between loan facilities and types of companies.

\section{TABLE - 12}

Percentage distribution of satisfaction level of employees with loan facilities. (Figures in parenthesis are in percentages)

\begin{tabular}{|c|c|c|c|c|c|c|c|}
\hline \multirow[t]{2}{*}{ Type of Company } & \multicolumn{3}{|c|}{ Motivation and Loan Facilities } & & & \multirow[t]{2}{*}{ Total } & \multirow[t]{2}{*}{ Index } \\
\hline & $\begin{array}{l}\text { Highly } \\
\text { dissatisfied }\end{array}$ & Dissatisfied & Neutral & Satisfied & $\begin{array}{l}\text { Highly } \\
\text { satisfied }\end{array}$ & & \\
\hline Domestic & $\begin{array}{l}19 \\
(19)\end{array}$ & $\begin{array}{l}43 \\
(43)\end{array}$ & $\begin{array}{l}34 \\
(34)\end{array}$ & $\begin{array}{l}4 \\
(4)\end{array}$ & $\begin{array}{l}0 \\
(0)\end{array}$ & $\begin{array}{l}100 \\
(100)\end{array}$ & -.24 \\
\hline Multinational & $\begin{array}{l}6 \\
(15)\end{array}$ & $\begin{array}{l}26 \\
(65)\end{array}$ & $\begin{array}{l}8 \\
(20)\end{array}$ & $\begin{array}{l}0 \\
(0)\end{array}$ & $\begin{array}{l}0 \\
(0)\end{array}$ & $\begin{array}{l}40 \\
(100)\end{array}$ & -.60 \\
\hline Total & $\begin{array}{l}25 \\
(17.9)\end{array}$ & $\begin{array}{l}69 \\
(49.3)\end{array}$ & $\begin{array}{l}42 \\
(30)\end{array}$ & $\begin{array}{l}4 \\
(2.9)\end{array}$ & $\begin{array}{l}0 \\
(0)\end{array}$ & $\begin{array}{l}140 \\
(100)\end{array}$ & -.34 \\
\hline
\end{tabular}

\section{Conclusion}

The overall condition of employee motivational programs in pharmaceutical companies is satisfactory. Employee motivation is a continuous process. So negligence by management to the employee's unfulfilled demands may cause frustration. Some financial programs need to be further developed. Motivational programs like promotion opportunities, transport facilities, canteen subsidy and loan facilities need to be implemented properly.

Despite the best effort of the researcher, the present study is not above some limitations. Here only seven companies from two categories have been brought under investigation. All employees of these seven companies were not investigated. One hundred and forty employees were interviewed. This is difficult to ensure that the numbers of the employees have reflected the picture of the whole sector. The research has been done on the Bangladesh perspective. Unemployment is the main problem in the society. So a person who can manage a job tries heart and soul to secure it. All motivational factors are not equally important to the employees. 
Pharmaceutical is a manufacturing industry. But this cannot be assured that the motivation programs of this industry will be equally applicable for others manufacturing industries in Bangladesh.

\section{References}

[1] Lester R. Bittel, and W. Newstorm John, What Every Supervisor Should Know (St. Louis: McGraw-Hill Inc. 1990, 253).

[2] Norman C. Hill, Increasing Management Effectiveness: Keys to Management and Motivation (Calif: Addision-Wesley Publishing, $1979,95)$

[3] Norman C. Hill, Increasing Management Effectiveness: Keys to Management and Motivation (Calif: Addision-Wesley Publishing, 1979, 84).

[4] Lester R. Bittel, and W. Newstorm John, What Every Supervisor Should Know (St. Louis: McGraw-Hill Inc. 1990, 250).

[5] Stephen E. Catt, and Donald S. Miller, Human Relations: Contemporary Approach (Illinois: Richard D. Irwin Inc., 1989., 135).

[6] Sarwar Zahan, Pharmaceutical: A Sector That is Delivering. Business Bangladesh, ${ }^{\text {st }}$ march, 2004, p. 22.

[7] Den Remenyyi, et al., Doing Research in Business and Management (London: SAGE Publications, 1998, 28).

[8] P.D Leedy, Practical Research Planning and Design (New York: Macmillan Publishing Company, 1989, p.67).

[9] Alan Bryman and Duncan Cramer, Quantitative data analysis with SPSS for windows (New York: Routledge, 1997, 16).

[10] Alan Bryman and Duncan Cramer, Quantitative data analysis with SPSS for windows (New York: Routledge, 1997, 172)

[11] Alan Bryman and Duncan Cramer, Quantitative data analysis with SPSS for windows (New York: Routledge,1997, 121-124).

[12] Norman c. Hill, Increasing managerial Effectiveness: Keys to Management and Motivation (Calif, Addision - Wesley Publishing, 1979, p 85).

[13] Mohammod Nurul Islam, Effectiveness of Motivation Programs of public Sector Banking in Bangladesh: A Study of Janata Bank , Unpublished Ph.D thesis, Rajshahi: IBS,1997, 138.

[14] J. D. Dunn, and Frank M. Rachel, Wages and Salary Administration: Total Compensation System (New York: McGraw Hill company, 1971, p.299). 